\title{
PRIMACY EFFECTS IN POLAND \\ - SUPPLEMENT TO STEVEN LINDER
}

\author{
Jacek Haman* \\ University of Warsaw
}

Abstract: The text supplements the article by S. Linder and contains information about research on the primacy effect in Poland. The subject of J. Raciborski's analyzes were elections to national councils (local government bodies) in 1988 - the last elections before the fall of communism in Poland, elections to the Sejm in 1989 and 1991. T. Źóttak investigated the existence of the primacy effect in the elections to the Senate in 1991-2007. However, the primacy effect in the 2014 regional elections was of greatest political importance. The strength of this effect was measured by J. Flis. Analyzes were also carried out on the effect of a candidate's position on the party semi-open list in proportional elections. However, this is a completely different issue, as in this case the position on the list is related to the actual political weight of the candidate.

In Poland, the relationship of the primacy effect with postal elections has never been studied, which results from the marginal importance of the latter, as well as the procedures used in elections, which prevent a separate analysis of the content of votes cast by post and at the polling station.

Key words: primacy effect, elections, voting.

\section{EFEKTY PIERWSZEŃSTWA W POLSCE - SUPLEMENT DO BADANIA STEVENA LINDNERA}

Streszczenie: Tekst stanowi uzupetnienie artykułu S. Lindera i zawiera informacje o badaniach nad "efektem pozycji na liście” (primacy effect) w Polsce. Przedmiotem analiz. J. Raciborskiego byty wybory do rad narodowych w 1988 roku (ostatnie wybory przed przełomem demokratycznym w 1989 roku), wybory do Sejmu w latach 1989 i 1991. T. Żóttak badat istnienie efektu pozycji $w$ wyborach do Senatu $w$ latach 1991-2007. Największe polityczne znaczenie

* Jacek Haman, Faculty of Sociology, University of Warsaw, ul. Karowa 18, 00-927 Warszawa, e-mail: jhaman@is.uw.edu.pl. The author would like to thank Steven Linder and Marek M. Kaminski for correcting the English version of the text. 
„efektu pozycji” miało miejsce $w$ wyborach regionalnych $w 2014$ roku. Pomiaru sity tego efektu dokonat J. Flis. Przedmiotem kilku analiz byt również efekt pozycji na liście partyjnej w wyborach proporcjonalnych - co jest jednak zupetnie osobnym zagadnieniem, gdyz w tym przypadku pozycja na liście powiazana jest z politycznym znaczeniem kandydata.

$W$ Polsce nie badano nigdy powiazania efektu pozycji z wyborami korespondencyjnymi - co wynika z marginalnego znaczenia tych ostatnich, a takze obowiazujacych procedur postępowania z głosami korespondencyjnymi, które uniemożliwiaja osobna analize treści głosów oddanych korespondencyjnie $i w$ sposób tradycyjny.

Stowa kluczowe: efekt pozycji, wybory, głosowanie.

From the point of view of the Polish editors, the article Primacy Effects and Mail Voting (Literature Review) by Steven Linder lacks references to research on primacy effects in Polish elections. It is difficult to blame the author for this since the literature on this subject is sparse and in Polish, but it is worth supplementing Linder's article.

The first study of primacy effects in Poland was published by Jacek Raciborski (1989) based on his observations of the 1988 national council (local-level governing bodies) elections. While held before the fall of the People's Republic of Poland in 1989, these elections were notable because of a change introduced to improve election competitiveness. Previously, ballots submitted with no marks were simply counted as votes for the first listed candidate. In 1988, candidates were instead listed alphabetically and voters had to cross out the names of candidates they did not want to vote for; with votes without any crossings invalidated. However, since candidates were not freely designated, such democratization of the election process was completely apparent, and the 1988 elections, although exceptional in the history of the People's Republic of Poland, are rarely mentioned by historians.

Raciborski's subsequent work (1997) analyzing the partially-free elections to the Sejm in 1989 would prove to be more important. In accordance with a compromise between the ruling communists and Solidarity, elections were held that would guarantee the communists and their allies a parliamentary majority throughout 1989. Elections would be held using a conventional majoritarian formula, but seats in each constituency were competed for separately and candidates for each seat would be either non-partisan or limited to members of certain parties. In practice, voters participated in two to five "single-mandate quasi-district" elections where some districts only had candidates from the Communist Party (PZPR), some were nonpartisan, and others limited to candidates belonging to allies of the communist party (ZSL and SD) or 
government-licensed organizations. Each constituency included at least one quasidistrict with PZPR members and one with nonpartisan candidates. ${ }^{1}$

Raciborski's analysis pointed to the existence of a primacy effect in the quasidistricts where PZPR and its satellites competed. A candidate's position on the ballot explained $13 \%$ of the variance in the percentage of votes they obtained. Additionally, the average result of candidates worsened as their position lowered; with first place candidates averaging $16.91 \%$ of the vote and eighth place candidates averaging $6.29 \% .^{2}$ In the nonpartisan quasi-districts where Solidarity candidates usually won by large majorities, the primacy effect was also observable, but much weaker. However, the observed effects were most likely spurious since the analysis did not take into account the number of competing candidates. ${ }^{3}$ Although Raciborski probably drew the wrong conclusion, the phenomenon he observed is still interesting because it showed a fundamental difference in the competitiveness between the non-partisan quasi-districts, where there was a clear support structure and a candidate's vote share was mainly determined by if they represented Solidarity, and the quasi-districts for PZPR and its satellites where there was no support structure for candidates and winners were more random.

In the same work, Raciborski then analyzed the 1991 elections to the Sejm, which were the first free parliamentary elections in post-war Poland. These elections were the first to use the current semi-open list proportional system where the order of candidates on the list is usually determined by political party leaders (implicitly listed from most-to-least important candidates), but some parties instead list candidates in alphabetical order. In these latter lists, Raciborski showed that the candidates placed first on the list gained a significant advantage that could not be explained by the differences in list length. The first place candidates on the "alphabetical" lists obtained on average 12 percentage points more than the candidates listed second, with this advantage being smaller in the non-alphabetized preferential lists (Raciborski 1997: 236). These results were possibly amplified by

1 More about the 1989 election law and about the reasons why, despite the guarantees contained therein, the communists did not retain power in Poland in (Kaminski 1999).

2 (Raciborski 1997:232). In the first round of the 1989 elections, the majority of voters in many constituencies crossed out all candidates in quasi-districts for the PZPR and its partners, so the sum of the percentages of votes for individual candidates was usually much lower than $100 \%$.

3 Suppose that in half of the districts there are two candidates, and in the other half of the districts are three candidates, and that the distribution of support for the candidates in each district is even; so in a district with two candidates each will get 50\%, and in a district with three candidates each will $33,33 \%$ of the vote. Under these conditions, the average support for the candidates from the first and second places on the ballot, half of which started from the districts with two candidates, and the half with three candidates, will amount to $41.67 \%$ each, and for the candidates taking the third place on the ballot (starting always from the districts with three candidates) $33.33 \%$, but in fact support does not depend on the position on the ballot, but on the number of competitors. The simulation of voting results in quasi-districts for the PZPR and its allies, assuming an equal distribution of votes (after deduction of votes cast against all candidates), leads to almost identical average support for candidates occupying subsequent seats, as provided by Raciborski. 
confusion among voters since for most lists a candidate's position carried significant information about his "importance." It was easy to then transfer this understanding to the few lists that were not supposed to provide such information. ${ }^{4}$

Raciborski basically did not examine primacy effects in the 1991 Senate elections; offering only one table showing averaged results depending on a candidate's ballot position and a one sentence comment stating there was no effect. A comprehensive analysis of the primacy effect in Senate elections was instead carried out by Tomasz Żółtak (2009) in his MA thesis. During the period covered by Żółtak's analysis, senators were elected in districts with between two and three (1991-1997) or two and four (2001-2007) seats. Each voter could vote for as many candidates as there were seats to be filled, which meant that several candidates from the same party often ran in the same constituency. Żółtak showed that a candidate's position on the ballot did not affect the result obtained by their election committee, but within the party a higher position on the alphabetically-sorted ballot was associated with a "bonus" of a few percentage points compared to colleagues located further down the list (Źółtak 2009: 58). The effect of positioning was also presented in a different manner - when two candidates from the same committee stood for two seats in one district, the candidate listed higher on the ballot frequently received between 55\% to 72\% more votes, depending on the election year (Żółtak 2009: 68). Thus in Senate elections, primacy effects actually turned out to be significant for competitions within parties, but insignificant in competitions among parties.

The primacy effect was found to be most important though during the 2014 local government elections ${ }^{5}$, when it contributed to a deep crisis of confidence in electoral institutions. A major source of this crisis was the discrepancy between the announced results of the regional assembly elections and the projected results from exit polls caused by the "booklet effect."

The "booklet effect" was associated with the use of "booklet ballots" in regional assembly and county council elections in place of the previously used "sheet ballots". Jarosław Flis (Flis, 2015, Flis \& Kaminski, forthcoming) estimated that in the county council elections, the committee list placed on the first page of the booklet received an approximate 6-8 percentage point boost in votes. This estimation, based on regression models, was possible thanks to a natural experiment where most counties had PSL (Polish People Party) listed first in the booklet, but in areas where PSL formed a coalition with other parties the booklet was opened by PiS (Law and Justice). Because

4 The impact of the position on the list reflecting the "importance" of the candidates is of course of a completely different nature. Even if selection of the first place candidate may sometimes result from laziness or a knowledge deficit, it can also be rational to trust in the party leaders' arrangement of the candidates. These effects (for Polish elections) are also subject to analysis, e.g. (Gendźwiłł and Raciborski 2014), (Marcinkiewicz 2014), (Marcinkiewicz and Stegmaier 2015).

5 This phenomenon also occurred, albeit on a smaller scale, in the 2010 local elections. 
of this, it was possible to model the results of a given party when it was listed first in a booklet against their results in other elections where they were listed lower.

The "booklet effect" was specific to the regional assembly and county council elections and did not impact elections to the Sejm despite their use of very similar "booklet ballots". Which is understandable in light of what is known about the factors contributing to the "primacy effect". In most local elections Polish voters receive four separate ballots for voting in four separate elections - mayors, municipal council members, county council members, and Sejmik (regional assembly) deputies. Most voters are primarily interested in the election of mayors and municipal councilors, and consider regional assembly and county council elections unimportant. Since the first regional assembly elections in 1998, this disinterest has consistently resulted in a high percentage of invalid votes. Most invalid votes take the form of "empty votes" (ballots without any annotation), or "multi-cross" votes where multiple candidates are selected when a vote must be cast for exactly one. The former may be treated as a direct effect of disinterest in the elections, while the latter testify to a misunderstanding of the rules, usually also caused by a lack of interest on the part of voters who, however - since they were given the ballot paper - decided to vote. The introduction of the new booklets in 2014 did not affect the number of "empty" votes, but did cause a large increase in "multi-cross" votes ${ }^{6}$, and votes for the party listed first in the booklet. In contrast, thoughtless votes cast on the "sheetballots" were scattered over many lists. In other words, the form of the ballot card was found to be irrelevant for conscious voting, but became essential in the county council and regional assembly elections where a large proportion of voters were uninterested. Such voters become particularly sensitive to factors that may confuse them and thus invalidate vote or unintentionally vote for the wrong party. In the Sejm elections, only people specifically interested in them bother to participate and know exactly who they want to vote for. This is evidenced by how the percent of invalid votes in Sejm elections are even lower than in the simultaneous Senate elections, despite the latter being procedurally simpler.

Although the estimated strength of the "booklet effect" made by Flis and Kaminski concerned the county council elections, the benefit was similar to the differences in results for PSL in regional assembly elections where it was the only beneficiary of the "booklet effect." In this case, the election commission results showed them with $23.9 \%$ of the vote, but exit-polls had estimated them receiving only $17 \%$. This aligns with the theory that the "booklet effect" was caused by voters

6 Although the regulations in force in 2014 did not provide for a separate counting of "empty" and "multicross" votes, the estimation of their number was possible thanks to the secondary analysis of the ballots carried out by the Batory Foundation; see (Gendźwiłł et al. 2016). For earlier (and later) elections, relevant data was collected directly by election commissions. 
who might not have paid attention to whom they voted for, and allows us to assume that the primacy effect in the regional assembly elections were similar to those in the county council elections.

Unfortunately, the above-described analyses of the primacy effect only concerned voting at the polling station since postal voting was only allowed in Poland starting in 2011. So among the analyzed elections it was only used marginally in the 2014 local elections. In accordance with ballot procedures, postal votes are also thrown by election commissions into the same ballot boxes as conventionally cast votes, making it impossible to obtain data on the number or characteristics of people choosing this form of participation in Polish elections.

\section{BibliOgRAPHY}

Flis, J. (2015). Efekt książeczki. In: Gendźwiłł, A., Rychard, A., Frydrych, A., Michalak, B., Rutkowski, J., Flis, J., Zbieranek, J., Co się stato 16 listopada? Wybory samorzadowe 2014. Warszawa: Fundacja im. Stefana Batorego.

Flis, J., Kaminski, M.M. (Forthcoming). Party-related primacy effects in proportional representation systems: Evidence from a natural experiment in Polish local elections. Public Choice.

Gendźwiłł, A., Materska-Sosnowska, A., Michalak, B., Haman, J., Flis, J., Zbieranek, J., Cześnik, M., Pietrzyk, P. (2016). Nieważne glosy, wazny problem. Raport z badania kart do głosowania $z$ wyborów do sejmików województw 2014. Warszawa: Fundacja im. Stefana Batorego.

Gendźwiłł, A., Raciborski, J. (2014). Jak głosują wyborcy w warunkach preferencyjnych list wyborczych: przypadek Polski. Decyzje, 22, 47-70.

Kaminski, M.M. (1999). How communism could have been saved: Formal analysis of electoral bargaining in Poland in 1989. Public Choice, 1(98), 83-109.

Marcinkiewicz, K. (2014). Electoral contexts that assist voter coordination: Ballot position effects in Poland. Electoral Studies, 33(March), 322-334.

Marcinkiewicz, K., Stegmaier, M. (2015). Ballot Position Effects Under Compulsory and Optional Preferential-List PR Electoral Systems. Political Behavior, 37(2), 465-486.

Raciborski, J. (1989). Rytuat, plebiscyt czy wybory? Socjologiczna analiza wyborów do rad narodowych w 1988 roku. Warszawa: Instytut Socjologii Uniwersytetu Warszawskiego.

Raciborski, J. (1997). Polskie wybory. Zachowania wyborcze społeczeństwa polskiego 1989-1995. Warszawa: Wydawnictwo Naukowe Scholar.

Żółtak, T. (2009). Wptyw miejsca na liście na wynik wyborczy w wyborach do Senatu RP. Unpublished master thesis, Institute of Sociology, Warsaw University. 